\title{
Ebelik Bölümü Öğrencilerinin Ebelik Mesleğine Bakış Açıları ve Gelecekten Beklentileri
}

\author{
Midwifery Department Students' Perspectives on Midwifery Profession and Their \\ Expectations from the Future
}

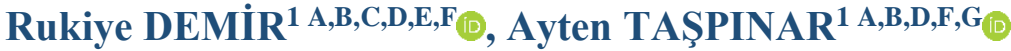 \\ ${ }^{1}$ Tekirdağ Dr. İsmail Fehmi Cumalıoğlu Şehir Hastanesi, Tekirdağ, Türkiye \\ ${ }^{2}$ Aydın Adnan Menderes Üniversitesi, Sağlık Bilimleri Fakültesi, Ebelik Anabilim Dalı, Aydın, Türkiye
}

ÖZ

\begin{abstract}
Amaç: Bu çalışma, ebelik bölümü öğrencilerinin ebelik mesleğine bakış açılarının ve gelecekten beklentilerinin belirlenmesi amacıyla yapılmıştır.

Yöntem: Araştırma tanımlayıcı olarak, Nisan-Mayıs 2018 tarihleri arasında, Aydın İlindeki bir devlet üniversitesinin sağlık bilimleri fakültesi ebelik bölümü öğrencileriyle yapılmıştır. Araştırmanın evrenini, ebelik bölümünde 2017-2018 eğitim yılında öğrenim gören toplam 349 öğrenci, örneklemini ise çalışmaya katılmayı kabul eden 162 öğrenci oluşturmuştur. Araştırmanın verileri "Veri Toplama Formu" ile toplanmıştır. Veriler Statistical Package for the Social Sciences 24.0 programı ile değerlendirilerek sayı, yüzde, ortalama, standart sapma dağılımları verilmiştir.

Bulgular: Araştırmaya katılan öğrencilerin \%45.7'si 21-22 yaş aralığında idi. Öğrencilerin \%38.9'u iş olanağı yüksek olduğu ve \%22'si puanı bu bölüme yettiği için, \%63'ü kendi isteği ile ebelik bölümünü seçtiği belirlendi. Çalışmaya katılan öğrencilerin $\% 51.8$ 'inin mezun olduktan sonra hastane ya da aile sağlı̆̆ı merkezlerinde çalışmak istedikleri saptandı. Öğrencilerinin \%44.2'si ülkemizde ebelik mesleğinin gelişimini yeterli/kısmen yeterli gördüğünü, \%86.4'ü ebelik bölümünde eğitime başladıktan sonra mesleğe bakış açısının olumlu yönde değiştiğini, \%71'i mesleğin kişilik özelliklerine uygun olduğunu, \%54.3'ü mesleki anlamda geleceğe bakış açısının olumlu olduğunu ve \%49.4'ü ebelik mesleğinin ileride herkes tarafından tercih edilmek istenen bir meslek olacağını bildirdi.

Sonuç: Araştırma sonucunda öğrencilerin büyük çoğunluğunun bölüm tercihlerini bilinçli yaptıkları, tercihlerinde mesleğin iş olanaklarının olması ve puanlarının düşük olmasının etkili olduğu, eğitim ile mesleğe olumlu bakış açısı geliştirdikleri, mesleğin geleceği ile ilgili olumlu düşüncelerinin olduğu ve mesleğin zorluklarının farkında oldukları sonucuna varılmıştır.
\end{abstract}

Anahtar Kelimeler: Ebelik, Bakış açısı, Beklenti, Meslek, Öğrenci.

ABSTRACT

Objective: This study was carried out to determine the perspectives of midwifery students about the midwifery profession and their expectations from the future.

Methods: Descriptively, the study was conducted between April and May 2018 with the midwifery department students of the health sciences faculty of a state university in Aydin. The population of the study consisted of 349 students studying in the midwifery department in the 2017-2018 academic year, and the sample of 162 students who agreed to participate in the study. The data of the study were collected using the "Data Collection Form". The data were evaluated using the Statistical Package for the Social Sciences 24.0 program, and distributions of numbers, percentages, mean and standard deviations were given. Results: $45.7 \%$ of the students participating in the study were in the 21-22 age range. It was determined that $38.9 \%$ of the students had a high job opportunity and $22 \%$ of them had enough points for this section, $63 \%$ chose the midwifery department voluntarily. It was determined that $51.8 \%$ of the students participating in the study wanted to work in hospitals or family health centers after graduation. $44.2 \%$ of the students think that the development of the midwifery profession is sufficient/partially sufficient in our country, $86.4 \%$ of them think that their perspective on the profession has changed positively after starting the

Sorumlu Yazar: Rukiye DEMİR

Tekirdağ Dr. İsmail Fehmi Cumalıŏlu Şehir Hastanesi, Tekirdağ, Türkiye

rukiye_kiymik@hotmail.com

Geliş Tarihi: 14.08.2020 - Kabul Tarihi: 05.04.2021

Yazar Katkıları: A) Fikir/Kavram, B) Tasarım, C) Veri Toplama ve/veya İşleme, D) Analiz ve/veya Yorum, E) Literatür

Taraması, F) Makale Yazımı, G) Eleştirel İnceleme 
midwifery department, $71 \%$ is suitable for the personality traits of the profession, $54.3 \%$ '̈̈ their professional perspective was positive and $49.4 \%$ stated that the midwifery profession would be preferred by everyone in the future.

Conclusion: As a result of the study, it was concluded that the majority of students made their choice of departments consciously, that their choice was job opportunities and their low scores were effective, they developed a positive perspective on education and the profession, they had positive thoughts about the future of the profession, and they were aware of the difficulties of the profession.

Key words: Expectation, Midwifery, Student, Vocation, Viewpoint.

\section{GíRiş}

Meslek, genel anlamda insanlara faydalı mal ve hizmet üretmek ve karşılığında para kazanmak için yapılan, planlı bir eğitim sonucunda elde edilen, sistemli bilgi ve becerilere dayalı, kuralları toplumca belirlenmiş etkinlikler bütünü olarak tanımlanmaktadır (1,2). Meslek, kişinin kimliğinin en önemli kaynağı olup, onun saygı görmesine, başkaları ile ilişki kurmasına, toplumda bir yer edinmesine olanak veren bir etkinlik alanı, yeteneklerini kullanma, kendini gerçekleştirme ve geliştirme yoludur (3). Meslek seçimi ise, bireyin yapmak istediği meslekler arasından birini seçmesi ve bu mesleğe sahip olması için çaba göstermesidir. Meslek seçimi, bireyin yaşam sürecinde en önemli kararlardan birisidir. Birey meslek seçimi ile birlikte belirli bir çalışma ortamını ve yaşam biçimini de seçmiş olur. Meslek seçim sürecini değer, ilgi ve inançları içeren birden fazla faktör etkileyebilmektedir $(4,5)$. Bireysel özellikler, aile ve toplumun yapısı, ülke politikası, ekonomik nedenler, iş bulma olanağı gibi birçok faktör bireylerin meslek seçimini etkilemektedir $(1,6)$. Meslek seçimi kişileri ve yaptıkları işi etkileyebilmektedir. Kişinin seçtiği mesleğe yönelik olumlu tutum ve görüşe sahip olması mesleğe uyumu artırmakta ve başarılı bir çalışma yaşamı sürdürmede ve mesleğin gelişiminde önemli rol oynamaktadır $(7,8)$. Kişilerin meslek bilinci öğrencilik yıllarında oluşmaya başlar ve meslek yaşamı boyunca devam etmektedir. Bu nedenle ebelik mesleğinin ilerlemesi, statüsünün yükselmesi için mesleği seçenlerin ilgi, istek ve yeteneklerini göz önünde bulundurmaları, mesleği iyi tanımaları, kabullenmeleri ve sevmeleri, mesleklerine karşı olumlu bakış açısı geliştirmeleri gerekmektedir $(4,9)$.

Mesleki beklenti, kişilerin gelecekte ne olabileceği ile ilgili çıkarımlarını ve gerçekleşmesini umdukları durumları içermektedir $(10,11)$. Bireyler, bir mesleğin eğitimiyle birlikte meslekle ilgili beklentilerini oluşturmaya başlamaktadırlar. Mesleki beklentiler mesleği isteyerek tercih etme durumu, mesleğini benimseme ve sevme durumu, meslek profesyonellerinin davranış ve tutumları ve mesleğin toplumdaki statüsü gibi çeşitli faktörlerden etkilenebilmektedir. Bu nedenle mesleğe ilk adımın atıldığı öğrencilik yıllarında, öğrencilerin mesleği nasıl algıladıklarının, mesleğe bakış açıları ve meslekten beklentilerinin belirlenmesi mesleki ve kişisel gelişimlerinde önemli rol oynamaktadır (12-14). Toplumun hızla değişen ve artan sağlık bakım taleplerinin karşılanmasında sağlık ekibinin en önemli üyesi olacak olan ebelik öğrencilerinin mesleklerine karşı olumlu bakış açısı geliştirmeleri ve gelecekten beklentilerinin karşılanması bu açıdan önemlidir. Literatürde, ebelik bölümü öğrencilerinin mesleğe bakış açılarına, mesleği algılamalarına ve gelecekten beklentilerine yönelik araştırmaların sınırlı sayıda olduğu görülmüştür (9,15-19). Ebelik bölümü öğrencilerinin mesleklerine bakış açıları ve geleceğe yönelik beklentilerinin belirlenmesi, mesleki memnuniyetlerinin artmasında, sağlık bakım kalitesinin yükseltilmesinde, yaşanılan mesleki sorunların belirlenmesi ve çözümlenmesinde yol gösterici olacağı düşünülmektedir. Bu 
nedenle bu araştırma, ebelik bölümü öğrencilerinin ebelik mesleğine bakış açılarını ve gelecekten beklentilerini belirlemek amacıyla yapılmıştır.

\section{GEREÇ VE YÖNTEMLER}

\section{Araştırmanın Türü ve Yapıldığı Yer}

Araştırma tanımlayıcı tipte tasarlanmış, Aydın ilindeki bir devlet üniversitesinin sağlık bilimleri fakültesi ebelik bölümü öğrencileriyle, Nisan-Mayıs 2018 tarihleri arasında yapılmıştır.

\section{Araştırmanın Evreni ve Örneklemi}

Araştırmanın evrenini, Aydın Adnan Menderes Üniversitesi Sağlık Bilimleri Fakültesi Ebelik Bölümü'nde, 2017-2018 eğitim yılında öğrenim gören toplam 349 (birinci sinıf 88, ikinci sınıf 87, üçüncü sınıf 93, dördüncü sınıf 81 kişi) öğrenci oluşturmuştur ( $N=349)$. Çalışmada evrenden örneklem seçimine gidilmemiş ve tüm evrene ulaşılmaya çalışılmıştır. Verilerin toplandığı gün ve saatte sınıfta olan, araştırmaya katılmayı kabul eden tüm öğrenciler çalışmaya alınmıştır. Sonuç olarak araştırmaya 162 öğrenci katılmıştır. Örneklem evrenin \%46.5'ini oluşturmaktadır.

\section{Verilerin Toplanması}

Araştırmanın verileri araştırmacılar tarafından literatür doğrultusunda (6,9,17-21) geliştirilen "Veri Toplama Formu" ile sorumlu araştırmacı tarafindan yüz yüze görüşme yöntemiyle derse girmeden önce ilgili dersin öğretim elemanından izin alınarak sınıflarında toplanmıştır. Veri toplama formu öğrencilerin sosyo-demografik özelliklerini, mesleğe bakış açılarını ve gelecekten beklentilerini içeren toplam 28 sorudan oluşmuştur. Veri toplama formu öğrencilere dağıtılmadan önce öğrencilere araştırma hakkında bilgi verilmiş ve çalışmaya katılmayı kabul eden öğrencilere formları dağıtılmıştır. Veri formlarının doldurulması yaklaşık 15-20 dakika sürmüştür.

\section{Verilerin Değerlendirilmesi}

Araştırmanın istatistiksel analizleri istatistik paket programı Statistical Package for the Social Sciences (SPSS) 24.0 kullanılarak yapılmıştır. Verilerin sayı, yüzde, ortalama ve standart sapma dağılımları verilmiştir.

\section{Araştırmanın Etik Yönü}

Uygulama öncesinde araştırmacılar tarafından tüm öğrencilere araştırmanın amacı, veri toplama formunun nasıl doldurulacağı hakkında açıklama yapılmış ve öğrencilerin sözlü ve yazılı onamları alınmıştır. Araştırmanın yürütülmesi için 2018 yılında Aydın Adnan Menderes Üniversitesi Sağlık Bilimleri Fakültesi Girişimsel Olmayan Klinik Araştırmalar Etik Kurulu'ndan etik kurul izni (No:218/11) ve Fakülte Dekanlığından kurum izni alınmıştır. Araştırmanın her aşamasında Helsinki Deklarasyonu prensiplerine uygun davranılmıştır. 


\section{BULGULAR}

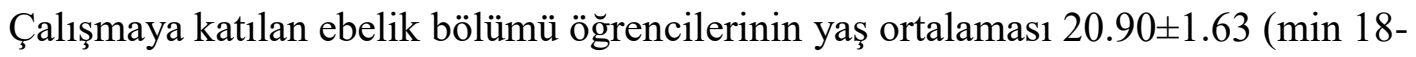
max 29)'dür. Öğrencilerin \%34.5'i birinci, \%14.2'si ikinci, \%24.1'i üçüncü, \%27.2'si ise dördüncü sınıfta okumaktadır. Öğrencilerin \%65.4'ünün Anadolu Lisesi mezunu, \%83.3'ünün çekirdek aile yapısına sahip olduğu, \%74.7'sinin ekonomik durumunu orta (gelir gidere denk) olarak algıladığı ve \%61.2'sinin 12 yaşına kadar ilçe/köyde yaşadığı belirlenmiştir (Tablo 1). Öğrencilerin annelerinin \%58.6'sının ilkokul ve ortaokul mezunu oldukları ve \%22.8'inin herhangi bir gelir getiren işte çalışmadıkları, babalarının ise \%53.1'inin ilkokul ve ortaokul mezunu oldukları ve \%72.8'inin gelir getiren bir işte çalıştıkları saptanmıştır.

Tablo 1. Öğrencilerin Sosyo-Demografik Özellikleri $(n=162)$

\begin{tabular}{llcc}
\hline Özellikler & & $\mathbf{n}$ & \% \\
\hline Sınıf & 1. sınıf & 56 & 34.5 \\
& 2. sınıf & 23 & 14.2 \\
& 3. sınıf & 39 & 24.1 \\
& 4. sınıf & 44 & 27.2 \\
\hline Yaş grubu & $18-20$ yaş & 65 & 40.2 \\
Yaş ortalaması $\pm \mathbf{S S}=\mathbf{2 0 , 9 0} \pm \mathbf{1 , 6 3}$ & $21-22$ yaş & 74 & 45.7 \\
& $23-29$ yaş & 23 & 14.1 \\
\hline Mezun olunan okul & Anadolu Lisesi & 106 & 65.4 \\
& Düz lise/AÖL* & 37 & 22.9 \\
& SML & 19 & 11.7 \\
\hline Aile yapısı & Çekirdek aile & 135 & 83.3 \\
& Geniş aile & 27 & 16.7 \\
\hline Ekonomik durum algısı & Gelir giderden az & 26 & 16.0 \\
& Gelir gidere denk & 121 & 74.7 \\
& Gelir giderden fazla & 15 & 9.3 \\
\hline 12 yaşa kadar yaşanılan yer & İçe/Köy & 99 & 61.2 \\
& İl/Büyükşehir & 63 & 38.8 \\
\hline
\end{tabular}

*Anadolu Öğretmen Lisesi

Çalışmaya katılan öğrencilerinin \%63'ü ebelik bölümünü kendi isteğiyle ve \%25.3’ü ailesinin önerisiyle seçtiklerini bildirmiştir. Öğrencilerden \%38.9'u iş olanağ yüksek olması ve \%22'si sınav puanının bu bölüme yetmesi nedeniyle seçtiğini belirtmiştir. Öğrencilerin \%55.6'sının üniversite tercihinde bölümün ilk beş tercihi arasında olduğu ve \%54.9' unun lise mezuniyetinin ilk yılında bu bölüme yerleştiği saptanmıştır. Öğrencilerin \%47.5'i öğrenim gördüğü ebelik bölümünden orta düzeyde memnun olduğunu, \%74.1'i yakın zamanda bölüm değiştirme düşüncesinin olmadığını ve \%62.3’ü ebelik bölümünde okumayı başkalarına önerebileceğini ifade etmiştir. Öğrencilerin \%51.8'i mezun olduktan sonra hastane ve aile sağlığı merkezi gibi yerlerde ebe olarak, \%35.2'si yönetici olarak, \%9.3'ü lisansüstü eğitim alıp akademisyen olarak ve \%3.7'si ebelik mesleğinin dişında bir alanda çalışmak istediklerini belirtmişlerdir (Tablo 2).

Çalışmaya katılan öğrencilerin \%44.2'si ülkemizde ebelik mesleğinin gelişimini yeterli/kısmen yeterli görürken, $\% 56.8$ 'i yetersiz olarak gördügünü ifade etmişlerdir. Öğrencilerin mesleğinin gelişimini yetersiz görmelerinin ilk üç nedeni, ebelerin hemşirelik mesleğine özgü alanlarda çalıştırılması (\%29.7), ebelerin eğitim seviyesinin düşük olması (\%16.7), ebeleri ve mesleği savunacak kuruluş/derneklerin az olması/yetersiz çalışması (\%15.6) olarak belirlenmiştir. Öğrencilerin \%74.7'si mesleğin gelişmesi için herhangi bir 
önerisinin olmadığını belirtmiştir. Ebelik mesleğinin gelişmesi için önerisi olanların \%25.7'si ebelik mesleği topluma iyi tanıtılmalı, toplum ebelik mesleği hakkında bilgilendirilmeli, \%18.5'i ebelerin çalışma şartları düzenlenmeli ve ekonomik iyileştirmeler sağlanmalı, \%11.3'ü ebeler haklarına sahip çıkmalı, \%9.3'ü derneğe ve sendikalara üye sayısı artmalı önerilerinde bulunmuşlardır (Tablo 3).

Tablo 2. Öğrencilerin Ebelik Bölümünde Eğitim Almaya İlişkin Düşünceleri (n=162)

\begin{tabular}{|c|c|c|c|}
\hline \multicolumn{2}{|l|}{ Düşünceler } & \multirow{2}{*}{$\begin{array}{c}\mathbf{n} \\
102\end{array}$} & \multirow{2}{*}{$\begin{array}{c}\% \\
63.0\end{array}$} \\
\hline Ebelik bölümünü seçme & Kendi isteği & & \\
\hline kararı & Ailesinin önerisi & 41 & 25.3 \\
\hline & Öğretmeninin önerisi & 17 & 10.5 \\
\hline & Arkadaşlarının önerisi & 2 & 1.2 \\
\hline \multirow{7}{*}{$\begin{array}{l}\text { Ebelik } \\
\text { nedeni }\end{array}$} & İş olanağ1 yüksek olduğu için & 85 & 38.9 \\
\hline & Puanı bu bölüme yettiği için & 48 & 22.0 \\
\hline & İlgi duyduğu bir meslek olduğu için & 35 & 16.0 \\
\hline & Öneri üzerine & 24 & 11.0 \\
\hline & Sınava tekrar girmek istemediği için & 20 & 9.1 \\
\hline & Saygın bir meslek olduğu için & 4 & 1.8 \\
\hline & $\begin{array}{l}\text { Bu mesleğe yeteneği olduğunu düşündüğü ve } \\
\text { özendiği için }\end{array}$ & 2 & 0.8 \\
\hline \multirow[t]{3}{*}{ Ebelik bölümü tercih sırası } & 1-5. sıra aralığında & 90 & 55.6 \\
\hline & 6-10. sıra aralığında & 34 & 21.0 \\
\hline & 11-21. sıra aralığında & 38 & 23.4 \\
\hline \multirow{3}{*}{$\begin{array}{l}\text { Ebelik bölümüne kaçıncı } \\
\text { girişte yerleştiği }\end{array}$} & İlk girişte & 89 & 54.9 \\
\hline & 2. girişte & 61 & 37.7 \\
\hline & 3. ve üzeri girişinde & 12 & 7.4 \\
\hline \multirow{5}{*}{$\begin{array}{l}\text { Ebelik bölümünde okumaya } \\
\text { ilişkin memnuniyet düzeyi }\end{array}$} & Hiç memnun değilim & 14 & 8.6 \\
\hline & Kismen memnunun & 34 & 21.0 \\
\hline & Orta düzeyde memnunum & 77 & 47.5 \\
\hline & Memnunum & 25 & 15.4 \\
\hline & Çok memnunum & 12 & 7.4 \\
\hline \multirow[t]{3}{*}{ Bölüm değiştirme düşüncesi } & Yok & 120 & 74.1 \\
\hline & Var & 13 & 8.0 \\
\hline & Bilmiyorum/kararsızım & 29 & 17.9 \\
\hline \multirow{3}{*}{$\begin{array}{l}\text { Ebelik bölümünde okumayı } \\
\text { başkalarına önerme durumu }\end{array}$} & Öneririm & 101 & 62.3 \\
\hline & Önermem & 31 & 19.2 \\
\hline & Bilmiyorum & 30 & 18.5 \\
\hline \multirow[t]{4}{*}{$\begin{array}{l}\text { Mezun olduktan } \\
\text { çalışmak istediği yer }\end{array}$} & $\begin{array}{l}\text { Hastane/aile sağlı̆̆ merkezi gibi yerlerde ebe } \\
\text { olarak görev yapmak }\end{array}$ & 84 & 51.8 \\
\hline & Yönetici olmak & 57 & 35.2 \\
\hline & Lisansüstü eğitim almak/akademisyen olmak & 15 & 9.3 \\
\hline & Ebelik mesleğinin dışında bir alanda çalışmak & 6 & 3.7 \\
\hline
\end{tabular}

Çalışmaya katılan öğrencilerin ebelik mesleğine bakış açıları incelendiğinde öğrencilerin \%75.3'ü ebelik bölümünde eğitime başlamadan önce mesleğe bakış açısının olumlu olduğunu, \%86.4'ü eğitimine başladıktan sonra olumlu olduğunu bildirmiştir. Öğrencilerin \%86.4'ü toplum sağlığının gelişmesinde ebelerin önemli role sahip olduğunu, \%81.5'i ebeliği kutsal bir meslek olarak gördüğünü, \%71'i ebeliğin kişilik özelliklerine uygun olduğunu ve \%64.8'i mesleğin statüsünün yüksek olduğunu, \%43.8'i mesleğin ekonomik imkânlarının yeterli olduğunu, \%56.8'i mezun olduktan sonra atanma kaygısı yaşamayacağını, \%48.1'i ebeliği yıpratıcı bir meslek olduğunu ifade etmişlerdir. Çalışmaya katılan öğrencilerin \%80.2'si toplumun ebeyi sadece doğum yaptıran kişi olarak tanımladığını, \%73.5'i toplumun ebe ve hemşireyi aynı olarak nitelendirdiğini ve \%50'si ebeliğin kutsal bir meslek olarak 
görüldüğünü ifade etmişlerdir. Öğrencilerin ebelik mesleğinden beklentileri incelendiğinde, \%73.5'i gelecekte mesleğinde yükseleceğine, \%71'i ebelik eğitimi almasının yaşam kalitesini artıracağına, \%60.5'i ebelik mesleğinin toplumda kabul görmesini sağlayacağına inandıklarını, \%29'u gelecekle ilgili hiçbir beklentisinin olmadığını belirtmiştir. Öğrencilerin \%64.2'sinin mesleğin statüsünün gelecekte daha iyi olacağını ve \%60.5'inin gelecekte ebelik eğitiminin daha iyi olacağını düşündükleri belirlenmiştir. Ayrıca \%51.9'u mesleğe yeni katılacak ebelerin şimdiki ebelerden daha bilgili olacaklarını belirtirken, \%49.4'ü gelecekte ebelik mesleğinin vazgeçilmez bir meslek olarak yerini alacağına inandıklarını belirtmişlerdir (Tablo 4).

Tablo 3. Öğrencilerin Ebelik Mesleğinin Gelişimine İlişkin Düşünceleri (n=162)

\begin{tabular}{|c|c|c|c|}
\hline Düşünceler & & n & $\%$ \\
\hline \multirow{2}{*}{$\begin{array}{ll}\text { Ebelik } & \text { mesleğinin } \\
\text { gelişimi } & \end{array}$} & Yetersiz & 92 & 56.8 \\
\hline & Yeterli/k1smen yeterli & 70 & 44.2 \\
\hline \multirow{7}{*}{$\begin{array}{l}\text { Ebelik mesleğinin } \\
\text { gelişememe nedenleri* }\end{array}$} & Ebelerin hemşirelik mesleğine özgü alanlarda çalıştırılması & 80 & 29.7 \\
\hline & Ebelerin eğitim seviyesinin düşük olması & 45 & 16.7 \\
\hline & $\begin{array}{l}\text { Ebeleri ve mesleği savunacak kuruluş/derneklerin az } \\
\text { olması/yetersiz çalışması }\end{array}$ & 42 & 15.6 \\
\hline & Ebeler arasında örgütlenme, birlik bilincinin yetersiz olması & 37 & 14.0 \\
\hline & Mesleğin yasal düzenlemesinin olmaması & 27 & 10.0 \\
\hline & Ebelerin haklarını koruyamamas1, savunamaması & 22 & 8.1 \\
\hline & Ebelerin mesleğinin gelişimini önemsememesi & 16 & 5.9 \\
\hline \multirow{2}{*}{$\begin{array}{l}\text { Ebelik mesleğinin } \\
\text { gelişmesi için önerisi } \\
\text { olma durumu }\end{array}$} & Yok & 121 & 74.7 \\
\hline & Var & 41 & 25.3 \\
\hline \multirow[t]{8}{*}{$\begin{array}{l}\text { Ebelik mesleğinin } \\
\text { gelişmesi için öneriler* }\end{array}$} & $\begin{array}{l}\text { Ebelik mesleği topluma iyi tanıtılmalı, toplum ebelik mesleği } \\
\text { hakkında bilgilendirilmeli }\end{array}$ & 25 & 25.7 \\
\hline & $\begin{array}{l}\text { Ebelerin çalışma şartları düzenlenmeli ve ekonomik } \\
\text { iyileştirmeler sağlanmalı }\end{array}$ & 18 & 18.5 \\
\hline & Ebeler haklarına sahip çıkmalı & 11 & 11.3 \\
\hline & Derneğe ve sendikalara üye sayısı artırılmalı & 9 & 9.3 \\
\hline & Ebelik yasası çıkarılmalı & 7 & 7.2 \\
\hline & Ebeler hemşirelik mesleğine özgü alanlarda çalıştırılmamalı & 7 & 7.2 \\
\hline & $\begin{array}{l}\text { Öğrenim sürecinde uygulamalarla ebelerin becerileri } \\
\text { geliştirilmeli }\end{array}$ & 7 & 7.2 \\
\hline & Ebelerin mesleği gelişimi için daha çok çalışmalı & 6 & 6.2 \\
\hline
\end{tabular}

Tablo 4. Öğrencilerin Ebelik Mesleğine Bakış Açıları ve Gelecekten Beklentileri (n=162)

\begin{tabular}{lccc}
\hline Öğrencilerin ebelik mesleğine bakış açıları & $\begin{array}{c}\text { Olumlu/ } \\
\text { Kismen } \\
\text { olumlu } \\
\mathbf{n}(\boldsymbol{\%})\end{array}$ & $\begin{array}{c}\text { Olumsuz } \\
\mathbf{n}(\boldsymbol{\%})\end{array}$ & $\begin{array}{c}\text { Fikrim } \\
\text { yok }\end{array}$ \\
$\mathbf{n}(\boldsymbol{\%})$
\end{tabular}


Tablo 4. Öğrencilerin Ebelik Mesleğine Bakış Açıları ve Gelecekten Beklentileri (n=162) (devam)

\begin{tabular}{|c|c|c|c|}
\hline Öğrencilerin ebelik mesleğine ilişkin düşünceleri & $\begin{array}{l}\text { Evet } \\
\text { n (\%) }\end{array}$ & $\begin{array}{l}\text { Hayır } \\
\text { n (\%) }\end{array}$ & $\begin{array}{c}\text { Fikrim } \\
\text { Yok } \\
\text { n }(\%)\end{array}$ \\
\hline $\begin{array}{l}\text { Mezun olduktan sonra atanma kaygısı yaşayacağımı } \\
\text { düşünmüyorum }\end{array}$ & $92(56.8)$ & $37(22.8)$ & $33(20.4)$ \\
\hline Yıpratıcı bir meslek olarak görüyorum & $78(48.1)$ & $54(33.3)$ & $30(18.5)$ \\
\hline Toplumun ebelik mesleğini tanımadığını düşünüyorum & $91(56.2)$ & $43(26.5)$ & $28(17.3)$ \\
\hline \multicolumn{4}{|l|}{ Öğrencilerin gözüyle toplumun mesleğe bakıș açıları } \\
\hline Toplum ebeyi sadece doğum yaptıran kişi olarak tanımlamakta & $130(80.2)$ & $14(8.6)$ & $18(11.1)$ \\
\hline Toplum ebe ve hemşireyi aynı nitelendirmekte & $119(73.5)$ & $24(14.8)$ & $19(11.7)$ \\
\hline Ebeliği kutsal bir meslek olarak görüyor & $81(50.0)$ & $38(23.5)$ & $43(26.5)$ \\
\hline \multicolumn{4}{|c|}{ Öğrencilerin gelecekte ebelik mesleğinden bireysel açıdan beklentileri } \\
\hline Gelecekte mesleğimde yükseleceğime inanıyorum & $119(73.5)$ & $7(4.3)$ & $36(22.2)$ \\
\hline $\begin{array}{l}\text { Ebelik eğitimi almamın benim yaşam kalitemi artıracağına } \\
\text { inanıyorum }\end{array}$ & $115(71.0)$ & $18(11.1)$ & $29(17.9)$ \\
\hline Ebelik mesleği toplumda kabul görmemi sağlayacak & $98(60.5)$ & $16(9.9)$ & $48(29.6)$ \\
\hline Gelecekle ilgili hiçbir beklentim yok & $47(29.0)$ & $83(51.2)$ & $32(19.8)$ \\
\hline \multicolumn{4}{|l|}{ Öğrencilerin ebelik mesleğinin geleceğine ilişkin düşünceleri } \\
\hline $\begin{array}{l}\text { Ebelik mesleğinin statüsünün gelecekte daha iyi olacağını } \\
\text { düşünüyorum }\end{array}$ & $104(64.2)$ & $30(18.5)$ & $28(17.3)$ \\
\hline Gelecekte aldığımız eğitimlerin daha iyi olacağını düşünüyorum & $98(60.5)$ & $30(18.5)$ & $34(21.0)$ \\
\hline $\begin{array}{l}\text { Mesleğe yeni katılacak ebelerin, şimdiki ebelerden daha } \\
\text { donanımlı ve eğitimli olacaklarını düşünüyorum }\end{array}$ & $84(51.9)$ & $46(28.4)$ & $32(19.8)$ \\
\hline $\begin{array}{l}\text { Gelecekte ebelik mesleğinin vazgeçilmez bir meslek olarak yerini } \\
\text { alacağına inanıyorum }\end{array}$ & $80(49.4)$ & $40(24.7)$ & $42(25.9)$ \\
\hline Mesleki anlamda, geleceğe bakış açım olumsuz & $33(20.4)$ & $88(54.3)$ & $41(25.3)$ \\
\hline
\end{tabular}

\section{TARTIŞMA}

Ebelik bölümü öğrencilerinin ebelik mesleğine bakış açıları ve gelecekten beklentilerinin belirlenmesi amacıyla yapılan bu çalışmada öğrencilerinin yaş ortalaması

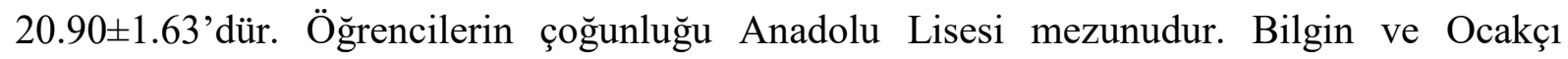
(2011)'nın ebelik öğrencilerinin mesleki güdülenme düzeylerini belirlemek amacıyla yaptıkları bir çalışmada araştırmaya katılan öğrencilerin yaş ortalamasının $21.45 \pm 2.07$ olduğu ve çoğunluğunun (\%69.5) düz lise mezunu olduğu saptanmıştır (22). Dinç ve ark. (2007)'nın yaptıkları bir çalışmada öğrencilerin büyük çoğunluğunun (\%81.0), Yiğit ve ark. (2007)'nın çalışmalarında da öğrencilerin yarısından fazlasının (\%58.0) düz lise mezunu olduğu belirlenmiştir $(7,23)$. Öğrencilerin yaş ortalamalarının literatürle benzer olduğu fakat öğrencilerin mezun oldukları okullar arasında farklılıklar olduğu görülmektedir. Öğrencilerin büyük çoğunluğunun düz liseden veya Anadolu Lisesinden mezun olmasının, Sağlık Meslek Liselerinin ebelik bölümlerinin 1996 yılında kapatılmış olması nedeniyle bu liselerden gelen öğrenci sayısının azalmasından, Anadolu Liselerinden gelen öğrencilerin ise ebelik bölümünü bir üniversiteye kayıt olma düşüncesinden, puanının bu bölüme yetmesinden ya da bölümün iş olanağının yüksek olmasından dolayı tercih ettiklerinden kaynaklanabileceğini düşündürmektedir.

Mesleği isteyerek tercih etme, kişinin hem öğrencilik hem de mesleki yaşantısında daha başarılı olmasına, mesleğini benimsemesine ve severek yapmasına, mesleki bilgi ve becerilerinin artmasına, olumlu benlik saygısı oluşturmasına ve profesyonelliğine olumlu katkı sağlamaktadır (16). Çalışmaya katılan öğrencilerin yarıdan fazlası ebelik bölümünü kendi isteğiyle, yaklaşık dörtte biri ailesinin önerisiyle seçtiğini ifade etmiştir. Yıldırım ve ark. 
(2014)'nın çalışmasında öğrencilerin \%62.5'i, Ünlü ve ark. (2008)'nın yaptığı çalışmada \%56.0'1, Yücel ve ark. (2018)'nın çalışmasında \%67.6'sı, Pınar ve ark. (2013)'nın çalışmasında ise öğrencilerin \%47.3'ü ebelik bölümünü kendi isteği ile seçtiğini ifade etmişlerdir $(16,19,24,25)$. Araştırmamızın bu sonucu literatür ile benzerlik göstermekte olup hem literatürde hem de çalışmamızda öğrencilerin çoğunluğunun kendi istekleriyle ebelik bölümünü tercih etmeleri mesleğin toplum ve gençler tarafından kabul gördüğünü göstermesi açısından sevindiricidir.

Meslek seçimi, bireyin istediği meslekler arasından birini seçmesi ve bunun için çaba göstermesidir. Bireyler meslek seçiminde birçok faktörün etkisi altında kalmaktadırlar (4). Çalışmaya katılan öğrencilerin ebelik bölümünü seçme nedenleri incelendiğinde öğrencilerin yaklaşık beşte ikisi ebelik bölümünü iş olanağının yüksek olması, beşte biri puanının bu bölüme yetmesi nedeniyle seçtiğini belirtmiştir. Özpancar ve ark. (2008)'nın ve Yücel ve ark. (2011)'nın ebelik bölümü öğrencileri ile yaptıkları çalışmalarında öğrencilerin ebelik bölümünü iş olanağı yüksek olmasından dolayı seçenlerin oranı yüksek bulunmuştur (\%53.0 ve \%50.7) (26,27). Ayrıca Atasoy ve Ermin (2016)'in yaptıkları bir çalışmada da öğrencilerin yarıya yakınının (\%44.0) ebelik bölümünü sadece diploma sahibi olmak için, Pınar ve ark. (2013)'nın çalışmasında iş bulma kolaylığından dolayı (\%32.3) ve ailesinin isteği nedeniyle (\%17.3) ebelik bölümünü seçtikleri görülmektedir $(16,21)$. Bu bulgulara göre öğrencilerin çoğunluğunun üniversite giriş puanının ebelik bölümüne yetmesi ve aynı zamanda gelecek endişesi yaşamaları ve ebeliği iş garantisi olan bir meslek olarak görmeleri nedeniyle tercih ettikleri görülmektedir. Ayrıca ailelerin ekonomik durumu, eğitim düzeyi öğrencinin meslek seçimini olumlu veya olumsuz yönde etkilemiş olabilir. Yapılan araştırmalar ekonomik düzeyi düşük ailelerin çocuklarının kısa sürede kazanç getirebilecek mesleklere yöneldiklerini göstermektedir $(4,9)$. Ülkemizde özellikle son yıllarda özel hastane sayılarının artması ebelik bölümü mezunlarına kolay iş bulma imkânı yaratmış olup sağlık çalışanlarının istihdamını artırmıştır. Bu hızlı gelişim hem toplumun hem de öğrencilerin ilgisini ebelik alanına yöneltmiş olabilir.

Çalışmaya katılan ebelik bölümü öğrencilerinin yarıdan fazlasının ilk kez girdikleri üniversite sınavında bu bölüme yerleştikleri, yine yarıdan fazlasının ebelik bölümünü ilk beş sırada tercih ettikleri bulunmuştur. Literatürde yapılan benzer çalışmalarda ebelik bölümünde okuyan öğrencilerin çoğunluğu üniversite giriş sınavında ebelik bölümünü onuncu ve daha sonraki siralarda tercih ettikleri ve önemli bir bölümü ikinci ve daha sonraki girişlerinde bu bölüme yerleştikleri belirtilmektedir (20,28-30). Çalışmamızda öğrencilerin yarıdan fazlasının bu bölümü ilk beş sırada tercih etmeleri ve yine yarıdan fazlasının üniversite sınavına ilk girişlerinde yerleşmiş olmaları ebelik mesleğinin istihdam alanının fazla olması nedeniyle tercih edilirliğini artırmış olmasından kaynaklanmış olabileceği gibi mesleğin toplum tarafından kabul edilirliğinin artmış olabileceğini gösterebilir.

Araştırmaya katılan öğrencilerin büyük çoğunluğunun ebelik bölümünde eğitim almaktan memnun olduklarını, yine büyük bir çoğunluğunun bölüm değiştirme düşüncesinin olmadığı, çoğunluğunun ebelik bölümünde okumayı başkalarına önerebileceklerini ifade ettikleri görülmektedir. Benzer şekilde Dinç ve Göktaş (2011) ve Atasoy ve Ermin (2016)'in yaptıkları çalışmalarda da ebelik öğrencilerinin çoğunluğunun bölümünden memnun oldukları ve mesleği yaşıtlarına tavsiye edecekleri belirlenmiştir (21,31). Öğrencilerin ebelik bölümünü okumaktan memnun olmaları öğrencilik yaşantısında başarılı, gelecekte profesyonel ebe ve diğer öğrenci meslektaşlarına rol model olmaları açısından önemli olduğunu düşünmekteyiz. 
$\mathrm{Bu}$ araştırmada öğrencilerin yaklaşık yarısı mezun olduktan sonra hastane ve aile sağlı̆̆ merkezi gibi yerlerde ebe olarak görev yapmak istediği belirtmiştir. Yücel ve ark. (2018)'nın yaptıkları çalışmada da ebelik öğrencilerinin \%46.8 i birinci basamak, \%52'si ikinci basamak sağlık kurumlarında çalışmak istedikleri görülmektedir (19). Yine Pınar ve ark. (2013)'nın yaptıkları çalışmada öğrencilerin yarısından fazlasının (\%58.6) ve Yurtsal ve ark. (2014)'nın çalışmasında öğrencilerin çoğunluğunun (\%78.5) mezun olduktan sonra ebe olarak çalışmak istediği saptanmıştır (16,30). Öğrencilerin ebe olarak daha kolay iş bulabileceklerini düşünmeleri, zaman kaybetmeden iş hayatına başlayarak erken dönemde ekonomik bağımsızlıklarını kazanmak istemeleri nedeni ile çoğunluğunun ebe olarak çalışmak istemiş olabileceklerini düşünmekteyiz. Ayrıca öğrencilerin yaklaşık yarısının aldıkları eğitime yönelik alanlarda, ebelik mesleğine ilişkin uygulamaları ve bağımsız rollerini etkin olarak uygulayabilecekleri hastane ve aile sağlı̆g merkezlerinde çalışmak istemelerini de memnuniyet verici olarak değerlendirmekteyiz. Öğrencilerin eğitimleri sırasında her basamaktaki sağlık kurumunda uygulaya çıkmalarının ve birinci basamağ 1 da tanımalarının bunda rol oynadığ düşünülebilir.

Öğrencilerin yaklaşık yarısı ülkemizde ebelik mesleğinin gelişimini yetersiz bulmaktadır. Mesleğin gelişmesine engel olan durumlar olarak ebelerin hemşirelik mesleğine özgü alanlarda çalıştırılmaları, ebelerin eğitim seviyesinin düşük olması, ebeleri ve mesleği savunacak kuruluş/derneklerin az olması/yetersiz çalışması ve ebeler arasında örgütlenme, birlik bilincinin yetersiz olmasını ifade etmişlerdir. Öğrencilerin ebelik mesleğinin gelişimini engelleyen nedenleri görmeleri ebelik mesleğinin profesyonelleşmesi konusunda daha bilinçli ebelerin yetiştiğini göstermesi bakımından sevindiricidir. Çünkü sorunun çözülebilmesi için önce sorunun varlığı tespit edilmesi gerekir düşüncesindeyiz.

Mesleğe ilişkin olumlu bir görüş ve tutuma sahip olmak hem meslek seçiminde hem de mesleğe uyum sağlamada verimli bir çalışma yaşamı sürdürme ve mesleğin gelişimini sağlamada önemli olmaktadır (4,32). Çalışmaya katılan öğrencilerin meslekle ilgili olumlu düşüncelerinin eğitim sonrası yükseldiği saptanmıştır. Ebelik öğrencileri ile farklı illerde yapılan çalışmalarda da benzer şekilde ebelik eğitimi almaya başladıktan sonra öğrencilerin sonra mesleğe bakış açılarının olumlu yönde geliştiği gösterilmiştir (19). Pınar ve ark. (2013)'nın çalışmalarında da öğrencilerin çoğunluğunun (\%75.5) okula başladıktan sonra meslekle ilgili tutumlarının olumlu olarak değerlendirdikleri, Yurtsal ve ark. (2014)'nın çalışmasında öğrencilerin eğitime başladıktan sonra tamamına yakının (\%96.8) düşüncelerinin olumlu yönde değiştiği ve Şahin ve ark. (2011)'nın yaptıkları çalışmada yarıdan fazlasının ebeliği ideal bir meslek olarak gördüğü $(\% 72.0)$ belirlenmiştir $(16,30,33)$. Eğitim sürecinde öğrencilerin aldıkları derslerle birlikte mesleği tanımalarını ve rollerini benimsemelerinin ebelik eğitimi sonrası mesleği olumlu değerlendirilmelerinde etkisi olabilir.

Çalışmaya katılan öğrencilerin yarısından fazlası toplumun ebelik mesleğini tanımadığını, büyük çoğunluğu ebeyi sadece doğum yaptıran kişi olarak tanımladığını ve ebe ve hemşireyi aynı nitelendirdiğini, yarısı ise toplumun ebeliği kutsal bir meslek olarak gördüğünü ifade etmiştir. Literatürde toplumun ebelik mesleğine bakış açısını inceleyen diğer araştırmalarda ebelik mesleğinin statüsünün toplumda düşük olduğu ve toplumun büyük bir bölümünün ebeyi sadece doğum yaptıran kişi olarak tanımladıkları görülmüştür (30,35-38). Yücel ve ark. (2017) yaptı̆̆ çalışmada ebelik öğrencilerin \%56.3'ü mesleğin toplumsal statüsünü orta olarak değerlendirmişlerdir (18). Araştırma bulguları toplumda ebelik mesleğine 
bakış açısı ile ilgili farklı sonuçların olduğunu göstermektedir. Günümüzde ebelik bakımı, dünyanın her yerinde sağlık bakımının önemli bir belirleyicisi konumundadır. Ancak bu kadar önemli ve kutsal görevi yerine getirmekle birlikte ebelik mesleği hem toplumsal hem de mesleki imaj açısından hak ettiği konuma gelememiştir. Hasta ve sağlıklı bireylere hizmet verirken ebelik bakımının sunum şekli ve ebelerin davranış şekilleri bireylerin ebelik imajını etkilemektedir. Toplumun bakış açısının olumlu olması öğrencilerin de motivasyonunu olumlu yönde etkileyebilmektedir (4). Bir mesleğin saygınlığını topluma verdiği hizmetin niteliği de etkilemektedir. Ebelik alanında günümüzde yaşanan gelişmeler ve ebelik eğitiminin lisansüstü seviyeye çıkması toplumun mesleğe bakış açısını olumlu yönde etkileyebileceği düşünülmektedir.

Başarılı olmak ve meslekten tatmin olmak için bireylerin mesleklerinden beklentilerinin araştırılması önem taşımaktadır. Çalışmaya katılan ebelik bölümü öğrencilerinin meslekten beklentileri incelendiğinde öğrencilerin büyük çoğunluğu gelecekte mesleğinde yükseleceğine ve ebelik eğitimi almasının onun yaşam kalitesini artıracağına inandığını belirtmiş, yarısından fazlası mesleğinden doyum alacağını ve üçte biri gelecekle ilgili hiçbir beklentisinin olmadığını ifade etmişlerdir. Ayrıca öğrencilerin yarıdan fazlası mesleğin statüsünün gelecekte daha iyi olacağını ve mesleğe yeni katılacak ebelerin şimdiki ebelerden daha donanımlı ve eğitimli olacaklarını düşündüklerini, yaklaşık yarısı ebelik mesleğinin vazgeçilmez bir meslek olarak yerini alacağına inandığını belirtirken, bir kısmı ise mesleki anlamda geleceğe bakış açısının olumsuz olduğunu ifade etmiştir. Atasoy ve Ermin (2016) çalışmalarında hemşirelik/ebelik öğrencilerinin çoğunun (\%88.0) gelecekte kolay iş bulma beklentisi içerisinde olduğunu, Özpancar ve ark. (2008) çalışmalarında öğrencilerin beklentilerinin meslek sahibi olmak (\%56.1) ve kariyer sahibi olmak (\%12.2) olduğu belirlenmiştir $(21,27)$. Bu bulgulara dayalı olarak öğrencilerin ebelik mesleğinden beklentilerinin ve mesleğinin geleceğine ilişkin düşüncelerinin genel olarak olumlu ve iyimser olduğu söylenebilir.

Araştırmaya katılan öğrencilerin yaklaşık yarısının "gelecekle ilgili hiçbir beklentim/fikrim yok" ve mesleki anlamda, "geleceğe bakış açım olumsuz/fikrim yok" dedikleri saptanmıştır. Öğrencilerin mesleki güdülenmelerini artırmaya yönelik eğitim faaliyetleri ile öğrencilerin gelecek beklentileri olumlu yönde geliştirilebilir. Ayrıca sosyal medyada olumlu ebe imajının oluşturulabilmesi için mesleki tanıtımların yapılması, öğrencilerin mesleki kongre, seminer ve toplantılara katılmaları ve bilimsel araştırmalarda görev almaları ile mesleki doyumları artabilir ve mesleki beklentileri olumlu yönde etkilenebilir.

$\mathrm{Bu}$ araştırmanın bazı sınırlılıkları bulunmaktadır. Bunlardan birincisi sadece bir devlet üniversitesinde yapılmış olmasından dolayı araştırma bulguları tüm ebelik öğrencilerine genellenemez. İkincisi, araştırma bulgularının araştırmaya katılan öğrencilerin kendi bildirimine dayanmasıdır. Bu yüzden sonuçlar, araştırma kapsamına alınan öğrencilerin vermiş oldukları yanıtlarla sınırlıdır. Üçüncüsü ise öğrencilerin çalışmaya katılmaya isteksiz olmalarından dolayı örneklem sayısının düşük olmasıdır.

\section{SONUÇ VE ÖNERÍLER}

$\mathrm{Bu}$ araştırmanın bulgularına dayalı olarak öğrencilerin büyük çoğunluğunun bölüm tercihlerini bilinçli yaptıkları, tercihlerini mesleğin iş olanakları ve giriş puanlarının düşük 
olmasının etkilediği, ebelik eğitiminden sonra mesleğe karşı olumlu görüşlerinin arttığ1, mesleğin gelecekte iyi konumda olacağı ile ilgili olumlu düşüncelerinin olduğu ancak mesleğin zorluklarının farkında oldukları sonucuna varılmıştır. Üniversiteye girecek öğrencilere ilgi duyduğu mesleklere yönelik tanıtım programlarının yapılmasını, öğrenci ebelere mezuniyetten sonraki çalışma alanlarının tanıtılarak, mesleğe farklı alanlardan bakış acısı kazandırılması ve seçtikleri mesleklere karşı olumsuz duygularının paylaşılması ve bu duyguların olumlu hale getirilmesinde bireysel görüşmelerin yapılmasını ve araştırmanın sınırlılıkları kapsamında çalışmanın daha farklı ebelik okullarında ve daha büyük örneklem grupları ile yapılması önerilebilir. Ayrıca sağlık kurumlarında geleceğe yönelik ebelerin beklentilerinin incelenerek, bu beklentiler yönünde gerekli iyileştirmelerin yapılmasının yararlı olacağı söylenebilir.

\section{Araştırmanın Etik Yönü}

Uygulama öncesinde araştırmacılar tarafından tüm öğrencilere araştırmanın amacı, veri toplama formunun nasıl doldurulacağı hakkında açıklama yapılmış ve öğrencilerin sözlü ve yazılı onamları alınmıştır. Araştırmanın yürütülmesi için 2018 yılında Aydın Adnan Menderes Üniversitesi Sağlık Bilimleri Fakültesi Girişimsel Olmayan Klinik Araştırmalar Etik Kurulu'ndan etik kurul izni (No:218/11) ve Fakülte Dekanlığından kurum izni alınmıştır. Araştırmanın her aşamasında Helsinki Deklarasyonu prensiplerine uygun davranılmıştır.

\section{Çıkar Çatışması}

Yazarlar herhangi bir çıkar çatışmasının olmadığını beyan etmektedir.

\section{KAYNAKLAR}

1. Yanıkkerem, E., Altınparmak, S., \& Karadeniz, G. (2004). Gençlerin meslek seçimini etkileyen faktörler ve benlik saygıları. Nursing Forum Dergisi, 7(2), 61-62.

2. Kızğut, S., \& Ergöl, Ş. (2011). Sağlık yüksekokulu öğrencilerinin hemşireliği algılayışı hemşirelik rollerine ve hemşireliğin geleceğine bakışı. Anadolu Hemşirelik ve Sağllk Bilimleri Dergisi, 14(2), 10-5.

3. Kuzgun, Y. (2009). Meslek gelişimi ve danışmanlı̆̆ . Ankara: Nobel Basımevi.

4. Halldorsdottir, S., \& Karlsdottir, S. I. (2011). The primacy of the good midwife in midwifery services: An evolving theory of professionalism in midwifery. Scand $J$ Caring Sci, 25, 806-817.

5. Yılmaz, M., \& Karadăg, G. (2011). Erkek öğrenci hemşireler hemşirelik mesleğini nas1l algilıyor? Maltepe Üniversitesi Bilim ve Sanatı Dergisi, 4(1), 21-8.

6. Genç, G., Kaya, A., \& Genç, M. (2007). İnönü Üniversitesi Tıp Fakültesi öğrencilerinin meslek seçimini etkiyen faktörler. İnönü Üniversitesi Eğitim Fakültesi Dergisi, 8(14), 49-63.

7. Dinç, S., Kaya, Ö., \& Şimşek, Z. (2007). Harran Üniversitesi Sağlık Yüksekokulu öğrencilerinin hemşirelik mesleği hakkındaki bilgi, düşünce ve beklentileri. Atatürk Üniversitesi Hemşirelik Yüksekokulu Dergisi, 10(1), 1-9.

8. Eşer, İ., Khorshid, L., \& Denat, Y. (2008). Hemşirelik mesleğini algılamada ilk klinik uygulamanın etkisi. Ege Üniversitesi HYO Dergisi, 24(1), 15-26. 
9. Ay, F., Keçe, M., İnci, İ., Alkan, N., \& Acar, G. (2018). Ebelik öğrencilerinin meslek algıları ve kariyer planlarını etkileyen faktörler. Balıkesir Sağlık Bilimleri Dergisi,7(2), 74-82.

10. Karaman, N. (2008). Öğretmenlerin mesleklerini algılama biçimleri ve gelecekten beklentileri nelerdir? (Yayımlanmamış Yüksek Lisans Tezi). Trakya Üniversitesi Sosyal Bilimler Enstitüsü, Edirne.

11. Tuncer, M. (2011). Yükseköğretim gençliğinin gelecek beklentileri üzerine bir araştırma. Turkish Studies-International Periodical for the Languages, Literature and History of Turkish or Turkic, 6(2), 935-948.

12. Önler, E., \& Varol Saraçoğlu, G. (2010). Hemşirelikte meslek seçimi ölçeğinin güvenilirlik ve geçerliliğii. Dokuz Eylül Üniversitesi Hemşirelik Yüksekokulu Elektronik Dergisi, 3(2), 78-85.

13. Hisar, F., Karadağ, A., \& Kan, A. (2010). Development of an instrument to measure professionel attitudes in nursing students in Turkey. Nurse Education Today, 30, 726730.

14. Çelik, B., Karadağ, A., \& Hisar, B. (2011). Instrument of prefessional attitude for student nurses: A confirmatory factor analytic study. Nurse Education Today, 30, 497500.

15. Şirin, A., Öztürk, R., Bezci, G., Çakar, Ç., \& Çoban, A. (2008). Hemşirelik öğrencilerinin meslek seçimi ve mesleği uygulamaya yönelik görüşleri. Dirim Tip Gazetesi, 83, 69-75.

16. Pınar, Ş., Cesur, B., Duran, Ö., Güler, E., Üstün, Z., \& Abak, G. (2013). Ebelik öğrencilerinin mesleki profesyonellikleri ve etkileyen etmenlerin incelenmesi. Ftrat Sağlık Hizmetleri Dergisi, 8(23), 1-19.

17. Karaçam, Z., \& Güleç, T. (2016). Yeni mezun ve öğrenci ebelerin kendilerini hemşire olarak tanıtma nedenleri. Ege Üniversitesi Hemşirelik Fakültesi Dergisi, 32(2), 11-24.

18. Yücel, U., Tuna, N., \& Yüksel, E. (2017). Ebelik öğrencilerinin meslek ile ilgili görüşlerinin ve mezuniyet sonrası çalışmak istedikleri kurumların değerlendirilmesi. Gümüşhane Üniversitesi Sağlık Bilimleri Dergisi, 6(4), 69-76.

19. Yücel, U., Ünal, İ., Özdemir, T., Koyuncu, M., \& Çakmak, N. (2018). Ebelik öğrencilerinin profesyonel değer algılarının belirlenmesi. Medical Sciences, 13(4), 94104.

20. Güner, S., Yurdakul, M., \& Yetim, N. (2015). Türkiye'de ebelik mesleğinin sorunlarına akademik bakışı yansıtan nitel bir çalışma. Yükseköğretim ve Bilim Dergisi, 5(1), 80-87.

21. Atasoy, I., \& Ermin, C. (2016). Hemşirelik ve ebelik öğrencilerinin mesleklerine bakış açısının incelenmesi. Düzce Üniversitesi Să̆llk Bilimleri Enstitüsü Dergisi, 6(2), 8391.

22. Bilgin, Z., \& Ocakçı, F. A. (2011). Ebelik öğrencilerinde mesleki güdülenme. Anadolu Hemşirelik ve Să̆lık Bilimleri Dergisi, 14(3), 40-6.

23. Yiğit, R., Esenay, F. I, \& Derebent, E. (2007). Türkiye'de hemşirelik son sınıf öğrencilerinin profili. Cumhuriyet Üniversitesi Hemşirelik Yüksekokulu Dergisi, 11(3), $1-10$.

24. Yıldırım, F., Çelik, F., Özmen, C., Erol, S., Üst, D. Z, \& Özkan, H. (2014). Ebelik bölümü öğrencilerinin ebelik mesleğinde erkeklerin yer almasına ilişkin görüşleri. Gümüşhane Üniversitesi Sağllk Bilimleri Dergisi, 3(1), 646-655.

25. Ünlü, S., Özgür, G., \& Gümüş, A. (2008). Hemşirelik yüksekokulundaki öğrencilerin hemşirelik mesleği ve eğitimi ile ilgili görüş ve beklentileri. Ege Üniversitesi HYO Dergisi, 24(1), 43-56. 
26. Yücel, Ç. Ş, Güler, K. E, Eşer, İ, \& Khorshid, L. (2011). İki farklı eğitim sistemiyle öğrenim gören hemşirelik son sınıf öğrencilerinin hemşirelik mesleğini algılama durumlarının karşılaştırılması. Ege Üniversitesi HYO Dergisi, 27(3), 1-8.

27. Özpancar, N., Aydın, N., \& Akansel, N. (2008). Hemşirelik I. sınıf öğrencilerinin hemşirelik mesleği ile ilgili görüşlerinin belirlenmesi. Cumhuriyet Üniversitesi HYO Dergisi, 12(3), 9-17.

28. Özdemir, M., Ercan, F., Sert, E., Hadıml1, A., \& Yücel, U. (2011). Ebelik ögrencilerinin mezuniyet sonrası kariyer gelişim planları ve lisansüstü ĕgitim konusundaki görüşleri. II. Ulusal Ebelik Öğrenci Kongresi Özet Kitabı.

29. Çiçek, Ü., Karagöz, B., Esen, S., Doğaner, G. (2011). Beklenti? Mesleki beklenti? Ebelik ögrencilerinin beklentileri? II. Ulusal Ebelik Kongresi Özet Kitabı.

30. Yurtsal, Z. B., Biçer, S., Duran, Ö., Şahin, A., Arslan, M., \& Yavrucu, Ö. K. (2014). Sağlık Bilimleri Fakültesi Ebelik 1. ve 4. Sınıf öğrencilerinin mesleğe ilişkin görüşlerinin belirlenmesi. Erciyes Üniversitesi Sağlık Bilimleri Fakültesi Dergisi, 2(2), 15-25.

31. Dinç, A., \& Göktaş, F. (2011). Ebelik bölümünden mezun öğrencilerin kariyer ve iş durumlarının incelenmesi. II. Ulusal Ebelik Öğrenci Kongresi Özet Kitab1.

32. Merih, Y. D., \& Arslan, H. (2012). Hemşire ve ebelerin mesleki bilinç-örgütlenmeye yönelik görüşlerinin ve iş doyumlarının belirlenmesi. Hemşirelikte Ĕgitim ve Araştırma Dergisi, 9(3), 40-46.

33. Şahin, S., Özdemir, K., Semiz, O., Gültekin, Z., \& Duman, E. (2011). Ebelik ögrencilerinin ebelik mesleğine ve eğitimine ilişkin bakış açıları. II. Ulusal Ebelik Öğrenci Kongresi Özet Kitabı.

34. Karaçam, Z. (2016). Türkiye'de profesyonel bir disiplin olarak ebelik mesleğinin durumu: yasal düzenlemeler, eğitim ve araştırma. Lokman Hekim Dergisi, 6(3), 128136.

35. Karaoğlu, L., Çelebi, E., \& Pehlivan, E. (2007). Nursing, midwifery and health officer programs undergraduate students' attitudes towards their future career: Motivating /demotivating professional characteristics and career preferences. İönü Üniversitesi Tip Fakültesi Dergisi, 14(4), 219-225.

36. Koç, Z., Bal, C., \& Sağlam, Z. (2010). Erkek öğrenci hemşirelerin hemşirelik mesleğini algılama durumlarının belirlenmesi. Maltepe Üniversitesi Hemşirelik Bilim ve Sanat Dergisi, Sempozyum Özel Sayıs, 318-323.

37. Demirci, H., Çınar, T., Can, G., \& Yükseksoy, B. (2011). Ebelik bölümü ögrencilerinin mesleği tercih etme nedenleri ve meslekten beklentilerinin incelenmesi. II. Ulusal Ebelik Öğrenci Kongresi Özet Kitabı.

38. Karahan, N. (2011). Türkiye' de ebe olmak. 1. Uluslararası \& II. Ulusal Ebelik Kongresi Kitab1. 